Corresponding Author:

A S Magomadov

gupvinhoz@mail.ru

Received: 25 October 2019

Accepted: 15 November 2019

Published: 25 November 2019

Publishing services provided by Knowledge E

(c) A S Magomadov et al. This article is distributed under the terms of the Creative Commons Attribution License, which permits unrestricted use and redistribution provided that the original author and source are credited.

Selection and Peer-review under the responsibility of the AgroSMART 2019 Conference Committee.

\section{New Agrotechnical Methods Development for Planting Material Production and Transplanting Young Grape Plants}

\author{
A S Magomadov1, G P Malykh², and A A Batukaev³ \\ ${ }^{1}$ Chechen State University, Grozny, Russia \\ ${ }^{2}$ All-Russia Scientific-Research Institute of Wine-making and Wine-Growing, Novocherkassk, \\ Russia \\ ${ }^{3}$ Chechen Scientific-Research Agricultural Institute, Chechen State University, Grozny, Russia
}

\section{Abstract}

The studies aim to evaluate the effect from agrotechnical methods on yield and quality of vegetative young plants that are used with new experimental facility. It provides for different modes in tops and roots zones of the same grafts, which dramatically increases the yield of circular-callus grafts. When using our facility at the end of stratification, when eyes of graft begin to sprout on shoots, they do not stretch out that provides nutrients preservation inside a plant, and grafts are not dried up. The experimental facility is used to grow young plants with a pre-vine trunk in a stratification chamber. A special polymeric-materials support was developed that allows to grow plants in its lower part, to plant them out in a permanent place, to place and hold the sleeves providing by it the yield increase trellis zone. The new method combines previously separated elements of vine-growing technology, starting from growing planting material to using fruit-bearing plantations into a single technological cycle in order to exclude a number of plant care activities, inter alia, protection plants from adverse weather factors, pests and diseases, and mechanical damage [20].

Keywords: engrafted young plants, substrates, experimental facility for young plants growing.

\section{Introduction}

One of the most important reserves of labor and funds saving in viticulture is development of robotic and automated means aimed at creating the optimal mode of growing high-quality young plants, their producing and planting to vineyards. They are to assist in increasing labor productivity and reducing a number of agricultural efforts based on planting care.

The issues relating to technique on grafts' stratification, planting material treatment against diseases and pests, optimal automated modes maintaining for growing plants are still poorly developed in domestic and world literature [19, 20]. 
To date it is known one serial electrification installation of the ESU-2 M (machinery markers in RF), where grafting during splicing are carried out through heating with wire, type POSHP-1-1, which is a steel wire with diameter of $1.1 \mathrm{~mm}$, and worn in polyethylene chlorvinyl sheath. The heating wire is laid out into wooden boxes with grafts; the boxes are filled with sawdust. For stratification, standard boxes are used (length $670 \mathrm{~mm}$, width $480 \mathrm{~mm}$ and height $600 \mathrm{~mm}$ ) with gaps between the slats up to $1 \mathrm{~cm}$ [1].

To put the grafted stems in a box, the end wall is to be taken off, and the box is set in an inclined position with the open side to the top. Sawdust is poured on the low-end wall with a layer of $5 \mathrm{~cm}$, starting from the left side, and a row of grafted stems is laid on the sawdust layer with their lower ends. Extreme grafted stems should be at distance of $5--6 \mathrm{~cm}$ from the sidewalls of the box. The graft part (the tops of the grafted stems) must be at the same level and for this a line or sliding bar are inserted on the inner walls of the box to which the tops of the grafts must reach.

Currently, open stratification technology intended to be used in environment of intensely humidified air has been developed.

Stratification chambers are usually heated with water heating and the required humidity of air in the chambers is maintained with water evaporation from special baths. For additional moistening and mold removal on grafted stems, they are periodically poured with water from special nozzles and ventilated with special fans.

The disadvantage of this technology concludes in its implementation complexity because with such stratification, the mold is intensively formed up and with what it is difficult to fight. After grafts are treated with pesticides, it is impossible to take the control over a grafts stratification process. Moreover, workers, leaving the chambers, might catch cold and other various diseases $[5,8]$.

We did not succeed to find in the literature anything about the issues relating to the technique for carrying out grafting stratification and growing vegetative young plants in one technological cycle. In climate conditions of our country, vegetative plants have not found practical application, and one of the main reasons for it lies in absence of equipment and low level of scientific developments towards technologies supporting growing.

The aim of this paper is to study in practice how the mechanical and automated means that we developed to create optimal conditions to grow young plants in one technological cycle.

To fulfill the aim stated, it was necessary to: 1) combine stratification, growing on the basis of new substrates; 2 ) to develop a new type of trellis to unite the disparate elements of the grape production technology, from growing young plants within the 
pots-based method -- up to exploitation of fruit-bearing plantations in one technological cycle; 3 ) to exclude a number of plant care activities, inter alia, their protection from adverse factors, pests, diseases and mechanical damage; and 4) to exclude such a time-consuming operation as rolling in vineyards.

\section{Methods and Materials}

With the aim to make observations, we applied methods that are widely used in wine growing.

\section{Results}

The facility testing that we designed for growing grafted vegetative young plants resulted in reduction of electricity consumption per one plant by 1.4--2 times. On average, the yield of grafted plants increases by $10-25 \%$. Good results were obtained when grafted vegetative plants were grown by farms in rooms adapted for these purposes in non-used premises. In so doing this case, new nursery facilities temporarily are not needed.

The operating principle of the facility: when the supply voltage is given to control unit 1 with the set temperature that is controlled by the temperature sensor 4 , the sand layer is heated with the help of heating element 3 . The steam generator qualitatively provides the necessary parameters not only of air temperature and humidity, but also of the substrate ensuring high output of the grafted young plants. The developed facility can be recommended to use in production in condition of studying thermotherapy, as a method of treatment towards fungal diseases and pests of grapes. Based on this facility, we developed the environmentally friendly method of disinfecting grape plants from grey rot during the period of their growing. For example, grey rot is an infectious disease. This micro fungus is developing well on dead plant parts and is considered to be a saprophyte. Grey rot is spread by conidia [7, 17, 18].

When collecting stalks in November-December, especially in mild and rainy weather, grey rot hyphae penetrates deeply into living tissue that results (when stored) in death of main and replacing buds, in appearing some spots on bark of stems with dead tissue. It is often the case that from a healthy-looking eye in the process of stratification of grafted stalks, a stem that is developing from a bud is affected by grey rot. It follows from the above that conidia must be destroyed by chemicals, when plants are yet in vineyards, that is, before harvesting stalks and re-laying them for storage. 
In Germany, quinosol (Chinosol W), consisting of $67 \%$ 8-hydroxyquinoline sulfate + $30 \%$ potassium sulfate, is used to treat the stalks.

In Hungary, solvokhin extra (Chinoin, Budapest) is used: 70 \% 8-hydroxyxygoline, 14 $\%$ potassium sulfate, $15 \%$ ethylenediamine-tetraacetic acid, $1 \%$ neutral fatty sulfate.

For disinfection, bundles of stalks of rootstocks and grafted varieties are completely soaked in $0.5 \%$ solution of quinosol. The soaking duration depends on water temperature: at $5{ }^{\circ} \mathrm{C}$ it lasts 5 hours, $10{ }^{\circ} \mathrm{C} \mathrm{--} 3$ hours, $20{ }^{\circ} \mathrm{C}-2$ hours. Soaking the stalks in quinosol is carried out after soaking them in water. Excessive concentration of disinfectant inside the stalks and on their surface adversely affects the formation of callus and roots, the development of buds and dramatically reduces the yield of plants.

All these listed chemical control measures are ineffective and dangerous to health of workers involved into plants cultivation. The currently used set of measures, agrochemical ad chemical methods for combating grey rot, can not tackle the problem towards protection against grey rot, especially when growing grape plants $[4,8,10]$.

The objective of the proposed invention is to increase the yield of grafted plants by destroying Botrytis cinere before stratification of rootstock, which dramatically reduces the emergence of eyes and reduces the cost of plants.

The novelty of the method to de described lies in the fact that for provocation of fungus development, a steam with temperature of $20--25^{\circ} \mathrm{C}$ and air humidity of $90--95$ $\%$ are used. Green cone formation from the eye of the rootstock with a height of 1.5--2 $\mathrm{cm}$ serves as an indicator of the complete germination of conidia 'Botrytis cineree', and then consistently and continuously t steam rises to $45--50^{\circ} \mathrm{C}$. Such a high t pair is kept for 10 minutes and it is a critical boundary after which the grey rot will die.

This technique provides not only the death of grey rot with minimal efforts and resources, but also the output of standard plants, their survival in a plantation, which will speed up the laying of new vineyards. The important fact is that with the aim to accelerate plants' reproduction and healing from a phytopathogenic infection, saturation of rootstock stalks with nutrients for better formation of callus, $0.2 \%$, the Albit solution is included into a composition of steam. The Albit contains the purified active ingredient poly- and beta-hydroxybutyric acid from the soil bacteria Bacillus megaterium and Pseudomonas aureofaciens. In natural conditions, these bacteria live in roots of plants, stimulate their growth, protect against diseases and adverse environmental conditions. The preparation also contains substances that enhance the effect of the main nutrient: a balanced starting set of macro and microelements ( $N, P, R, M g, S, F e, M n, ~ M o, ~ C u$, $\mathrm{Co}, \mathrm{B}, \mathrm{I}, \mathrm{Se}, \mathrm{Na}, \mathrm{Ni}, \mathrm{Zn}$ ) and the terpene acids of coniferous extract. The Albit does not contain living microorganisms (only DV of them), which makes the drug more stable, 
less susceptible to environmental conditions. The Albit is characterized by a low cost and by environmental friendliness of biological substances, while at the same time it approaches the chemical ones in its efficiency and stability.

We offer the second facility to grow young plants. With the aim to identify the optimal mode to grow young plants and seedlings, the heat shield that we developed was under testing. The shield consisted of high-density polyethylene tubes with a diameter of 30 $\mathrm{mm}$. To construct the entire area of greenhouses, the river sand was applied with a layer of $8--10 \mathrm{~cm}$, the heat shield tubes were laid along according to $40 \times 40 \mathrm{~cm}$ scheme that makes the shield of $160 \mathrm{~cm}$ wide, over which the sand layer of $3--5 \mathrm{~cm}$ was poured. Along the heat shield there are installed the flats, the width -- $180 \mathrm{~cm}$, which were covered with plastic black film, the thickness of which was 200 microns.

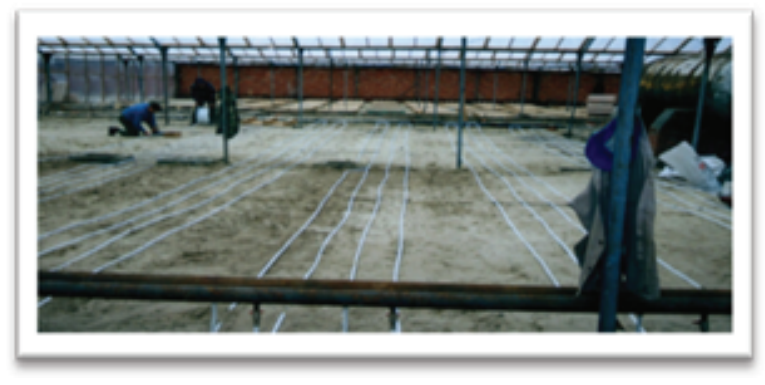

Figure 1: Heat shield in polyethylene greenhouses.

The heat shield to have been installed created the differential temperature mode: $22--23{ }^{\circ} \mathrm{C}$-- under the flats in a root zone; $14--16{ }^{\circ} \mathrm{C}$-- air in a greenhouse (close to the optimum temperature).

The heat shield provided a higher yield of young plants compared to the second unit, where a greenhouse heating was carried out with heat generators. The important role in cultivation of young plants plays substrates. However, vegetative plants required such substrates that would ensure not only good growth in green houses but also, more principally, their high survival rate in plantations.

Grafted stalks preparation and their planting in greenhouses. To cultivate the grafted young plants, the grafting is better to fulfill in February-March. The best way to carry out the bandaging of grafts is photo-destructible sleeves of F-535 within the technology developed by G. Malykh [3]. For bandaging the graft is placed in 250-mmlong sleeve with a melted upper part, $10--15 \mathrm{~mm}$ wide more than a grafting diameter, and then, it is dipped for $1--2 \mathrm{~s}$ into melted vaseline oil with temperature of $150--200^{\circ} \mathrm{C}$ and immediately placed in cold water. 


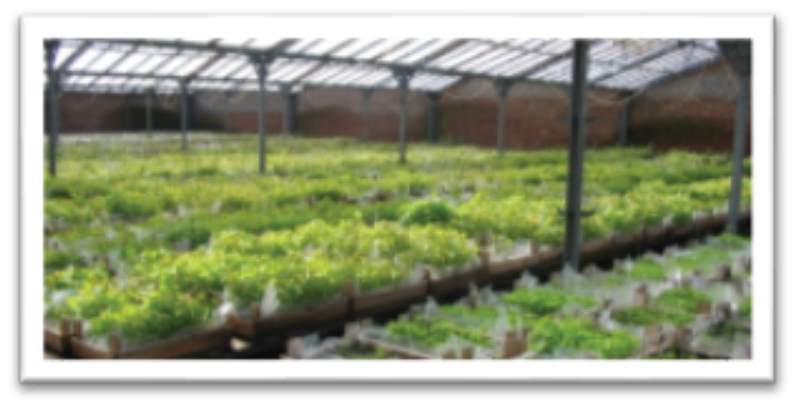

Figure 2: Young plants in polyethylene greenhouses.

Due to the high force of shrinkage, it tightly compresses a joint-place of a rootstock with a graft. After the end of life cycle (45 days), a photo-destructive film decomposes in day light, and then, it is finally destroyed by microorganisms $[4,10,15]$.

Time for planting. Vegetative young seedlings should be planted in vineyards in the conditions of the Chechen Republic from May 10 to June 10. The highest survival rate is observed, when planting in the first half of June, when conditions are most favorable for root system development.

Plants to be purchased in other farms should be planted into a permanent place of growing no later than 3 days (warranty period of storage in a shaded and non-windy place).

When planting vegetative seedlings, they raise a cap to the top, freeing the roots from the bottom and at the top, a cap/spathella is tied with a string over the heel root system, and above at a spike place, as shown in Figure 8 . Then, a vegetative seedling is planted in the center. The hole is covered by the half with soil and watered (10--15 liters). When water has been absorbed, the hole is covered with soil fully. It is advisable to leave around the seedlings a hole for next watering. At the same time, the place of spiking in grafted seedlings should be placed $5--6 \mathrm{~cm}$ above the soil level. After 7--10 days, depending on weather conditions, the second watering is undertaken and in 25--30 days, the third one is expected.

It is recommended to combine the second and third watering with mineral fertilizing and with re-planting of seedlings that have been fallen.

With such abundant watering roots are easier to release and their going beyond the substrate. When planting, a cap should rise $10 \mathrm{~cm}$ above the soil level. It is necessary to carefully avoid embedding the upper edge of a cap at or below the soil level, since in this case, the roots will grow above a cap and they would be ineffective.

In 2014, the grown grafted vegetative seedlings, planted in the winery 'Burunny' of Shelkovsky district in the Chechen Republic, were 88.8--95.7\%. At that time, the same 
variety 'Avgustin' was planted in the first decade of August in 2015 in another winery in Novocherkassk in the experimental zone; it showed the survival rate of only $68 \%$. Young plants at such a late planting did not prepare to winter, the increment did not ripen and all plants died.

The idea of the new planting method lies in planting seedlings with a closed root system, with a ready grafting horizontal cordon that is viewed as 10 rows in one direction and 10 rows in the other one.

This will reduce the thinning of grafted plantations at mechanized covering and increase their longevity (life) and productivity.

The support from polymeric materials is mounted from separate cones 1 and from a support ring 2 (fig. 3). The cone consists of identical halves.

When a grape is inserted into a low cone in a support, which is filled with substrate, one graft or stalk of $50--55 \mathrm{~cm}$ length is planted.

As a grape bush grows, the next cone is installed and a stem is inserted into it. Thus, consistently, cones are stepped up on each other, and a support is assembled to the required height.

The method eliminates an individual care and shaping up a vine trunk in a grape bush, which leads to a large reduction in manual labor cost.

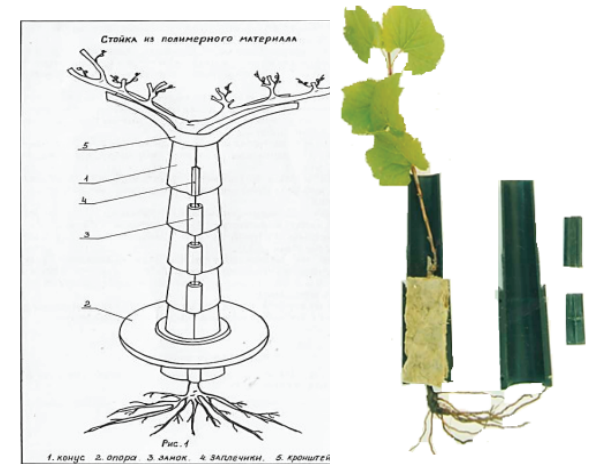

Figure 3: Polymeric material support.

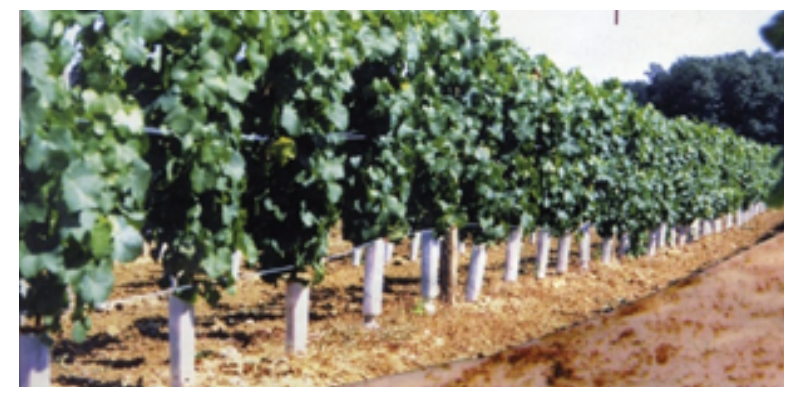

Figure 4: Vineyards with polymeric support. 


\section{The method to be proposed:}

1. Provides protection of vine trunks and sleeves of grape bushes from being affected by critically low temperatures;

2. Allows to construct straight and sustainable vine trunk of the required height;

3. Increases grape yielding due to improved conditions for plant developing;

4. Protects sleeve vine trunk of grape bushes from mechanical damage that enables to process soil mechanically in rows and between when young plants are placed;

5. Eliminates dew roots appearing, which inhibits the spread and development of phylloxera;

6. Excludes katarovka (grape surface roots deletion) -- one of the most labourconsuming activity in vine-gardening;

7. Allow to replace concrete and wooden support structures with light plastic ones;

8. Ensures a cost reduction by two times compared to the methods in use. The supports to be constructed within the technology described are using for 10 years up to the time when vineyard is renewed. The supports' construction is lighter by 8 times than the same ones made from concrete material.

Reduces labour-consuming in activities on gardening cares, typical to wine growing, by $27 \%$. The facilities are proposed to use in vine gardening are plain, therefore the engagement of high qualified specialists is not needed.

Technical solution has been patented in 13 countries.

\section{Conclusion}

The facility that we developed allows to conduct stratification and young plants growing in a micro-greenhouse within one technological cycle. This enables to significantly increase the quality and yield. The research targeted at fight with pests and diseases with the help of steam at temperature of $45--50{ }^{\circ} \mathrm{C}$ showed encouraging results. The steam generator qualitatively provides within the stated parameters not only the temperature and air humidity and a substrate, but also the feeding mode for young plants. While studying thermotherapy as a treatment method geared at viral fungi and the other damage to grape, the facility to be discussed can be effectively used. Application of developed technological approaches including technologies for planting material and 
advancements in ways to planting and in gardening care allows to increase the yield and quality of seedlings, their survival rate in plantations and productivity in general.

\section{References}

[1] Malykh, G.P., Kravchenko, L.V., Malykh, P.G., Muzychenko, B.A. The Method of Producing Grapes Saplings, no. 163950S USSR A 01G17/00, Applicant: NPO "Grape". No.4681276/15. Claims 04/20/89; publ. 04/07/91. Bul. no. 13, 2 p.

[2] Malykh, P., llyashenko, O.M. Method of grape winter grafting, no. 1158097 USSR, A 01G 1/06,. Applicant: S-R Institute named after Ya.I. Potapenko. No. 3613572 / 30-15; declare 04/20/83; publ. 05/30/85. Bul. no. 20, 2 p.

[3] Malykh, G.P., Zelenkova, T.N. Photodegradable Composition based on Polyethylene, no. 1040768 USSR, A 01 G 1/06, Applicant: NGO "Grapes" and Kuban Agricultural Institute. (USSR). No.3308818/13; declare 07.07.81; publ. 10.05.83, Bul. no. 23, 2 p.

[4] Malykh, G.P, Muzychenko, B.A. et al. Support for the Cultivation of Grapes, no. 1075460 Russian Federation, Applicant: patent holder of S-R Institute named after Ya.I. Potapenko.

[5] Batukayev, A.A., Magomadov, A.S. (2015). Scientific Substantiation of Technologies for Growing Seedlings and Ensuring the Physiological Need of Grapes for Trace Elements in Agro-ecological Conditions of the Terek-KumSsands. Grozny: Publishing House of the Chechen State. University, $167 \mathrm{p}$.

[6] Abrasheva, P. (1991). Prouchvaniya v"rhu nyakoi virusni i virusopodobni zabolyavaniya po lozata v B"Igariya i borba s ikonomicheski vazhnite ot tyah. Pleven, 342 p.

[7] Bobev, S. (2000). Spravochnik za bolesti po kulturnite rasteniya. Sofia: PublishSaySet-EKO, 255 p.

[8] Malykh, G.P., Magomadov, A.S. (2014). Wine-growing Glossary = Glossarij po vinogradarstvu. Novocherkassk: S-R Institute named after Ya.I. Potapenko, 642 p.

[9] Maltabar, L.M. (2009). Grape Nursery. Krasnodar, 289 p.

[10] Malykh, G.P., Magomadov, A.S. 2013. Viticulture of the Chechen Republic = Vinogradarstvo CHechenskoj Respubliki. Novocherkassk. 268 p.

[11] Malykh, G.P., Yakovtseva, O.L., Magomadov, A.S., Zubova, T.A. (2015). Graviomorphological Method of Creating Seedlings = Graviomorfologicheskij sposob sozdaniya sazhencev. Journal Wine-making and Viticulture, no. 2, pp. 52--55.

[12] Malenin, I. (1996). Diseases in Grape Gardening = Bolesti po lozata. Sofia: GlobalAgro, $151 \mathrm{p}$. 
[13] Martinov, S. (1952). Oidium po Losata. Losariy and Winery, no. 3, pp. 95--98.

[14] Malykh, G.P., Magomadov, A.S., Yakovtseva, O.L., Kerimov, V.S. (2016). Modern Technologies in Grafted Vegetative Seedlings and Planting Vineyards with them. Novocherkassk, p. 36.

[15] Malykh, G.P., Magomadov, A.S. (2013). Substratum for Vegetative Saplings of Grapes $=$ Substrat dlya proizvodstva vegetiruyushchih sazhencev vinograda. Wine-making and Viticulture, no. 6, pp. 40--44.

[16] Malykh, G.P., Kiseleva, T.G., Kiselev, I.E. Patent No. 2146440 Russian Federation, IPC A 01 G 17/02. Method for Obtaining Grape Grafts. Applicant patent holder NPO "Grapes". No. 98121264/13; declare 26.1198, publ. 03/20/2000. Bul. no. 8 (Chapter 1). $8 \mathrm{pp}$.

[17] Malykh, G.P., Kravchenko, L.V., Malykh, P.G., Kiseleva, T.G. Patent No. 2332837 Russian Federation, MPK7 A 01 G 17/00. The Method of Healing of Grapes Saplings. Applicant: patent holder of S-R Institute named after Ya.I. Potapenko.

[18] Malykh, G.P., Magomadov, A.S., Carnation, V.I., Yakovtsev, O.L. Patent No. 26, 26722. Method and Device for Combating Botrytis Cinerea in Growing Graft Saplings of Grapes.

[19] Raikov, E. (1949). Opazvane na grozdeto ot bolestta oidium (pepelnica). Lozarski pregled, no. 6, pp. 172--175.

[20] Raikov, E.P. (1971). Bolesti i nepriyateli po lozata. Sofia: Zemizdat, 199 p. 